MODELOVANJE KAO NAČIN UPRAVLJANJA NEIZVESNOŠĆU

PANDEMIJE: PROCENA SMRTNOSTI U KOVID-19 PANDEMIJI

PREGLEDNI RAD

REVIEW ARTICLE

\title{
MODELING AS AN APPROACH TO PANDEMIC UNCERTAINTY MANAGEMENT: MORTALITY ASSESSMENT OF THE COVID-19 PANDEMIC
}

\author{
Aleksandar Stevanović ${ }^{1,2}$, Milena Šantrić Milićevićc ${ }^{1,2}$ \\ ${ }^{1}$ Institut za socijalnu medicinu, Medicinski fakultet, Univerzitet u \\ Beogradu, Beograd, Srbija \\ ${ }^{2}$ Centar-Škola javnog zdravlja i menadžmenta u sistemu \\ zdravstvene zaštite, Medicinski fakultet, Univerzitet u Beogradu, \\ 1 Institute of Social Medicine, Faculty of Medicine, University of \\ Belgrade, Belgrade, Serbia \\ 2 Center-School of Public Health and Health Managemen, \\ University of Belgrade, Belgrade, Serbia
} Beograd, Srbija

\section{SAŽETAK}

Progresija KOVID-19 pandemije motivisala je medicinsku i naučnu zajednicu da pokuša da modeluje i predvidi transmisiju SARS-KoV-2 virusa. Predviđanje mogućeg toka KOVID-19 pandemije je pomoglo da bolje razumemo nijanse u efektima usvojenih mera, kao i da se usmerimo ka budućim merama koje bi trebalo sprovesti. U ovom radu smo pokušali da sumiramo nekoliko odabranih pristupa koji su korišćeni za procenu efekata KOVID-19 pandemije, kako na globalnom tako i na lokalnom nivou (Srbija).

Ključne reči: KOVID-19, pandemija, predviđanje, mere politike

\section{ABSTRACT}

The progression of the COVID-19 pandemic has urged the medical and scientific community to attempt to model and predict the transmission of SARS-CoV-2. Forecasting the possible course of the COVID-19 pandemic has helped us to better understand the nuances in the effects of the adopted policy measures and has directed us towards future actions which may need to be undertaken. In this article, we briefly summarize several selected projection approaches used for estimating COVID-19 effects globally and locally (Serbia).

Key words: COVID-19, pandemic, forecasting, policy measures

Primljeno • Received: September 3, 2021; Revidirano • Revised: September 14, 2021; Prihvaćeno • Accepted: September 16, 2021; Online first: September 30, 2021. 


\section{UVOD}

Kako su se povećavala dostupna saznanja o novom korona virusu, uzročniku blagih ali i ozbiljnih infekcija, sa mogućim prisustvom asimptomatskih prenosilaca u opštoj populaciji, tako se povećavala i neophodnost za hitnim delovanjem, sa ciljem da se spreče zdravstveni problemi obolelih, invaliditeti i ekonomski gubitak [15]. Moguće prednosti implementiranih mera za ublažavanje pandemije KOVID-19 oboljenja procenjuju se ne samo na osnovu njihovih efekata na tok pandemije već i na osnovu procene njihovih direktnih i indirektnih posledica na privredu i društvo u celini $[6,7]$.

Širenje pandemije KOVID-19 oboljenja podstaklo je mnoge profesionalne planere da pokušaju da sačine modele tekućih i budućih transmisija novog virusa SARS-KoV-2 sa ciljem da se postigne bolje razumevanje njegovih efekata u različitim okruženjima. Epidemiološke, političke, regulatorne promene, promene u društvenom ophođenju, kao i sve veća saznanja i sve veći broj podataka, iskorišćeni su kako bi se formulisale mnogobrojne pretpostavke i fleksibilne procene različitih oblika izloženosti ljudi ovom virusu, kvaliteta lečenja i ishoda. Novi pristupi ovim projekcijama, koji koriste najnovije podatke za poboljšavanje ovih modela, se stalno pojavljuju [6,7]. Obavezna primena različitih javnozdravstvenih mera u borbi protiv bolesti KOVID-19, kao i mere podrške i obuzdavanja širenja bolesti, predstavljaju odluke državnih zvaničnika i prevashodno se donose sa ciljem da se zaštite zdravlje i životi ljudi [8,9]. Na primer, propisi koji se odnose na socijalnu distancu i nošenje zaštitnih maski za lice, doneti su na osnovu načina prenošenja ove varijante virusa, mobilnosti i gustine naseljenosti stanovništva, kao i sveukupnog odgovora javnosti na pandemiju. Brza akumulacija podataka iskorišćena je za procenu i praćenje različitih epidemioloških i kliničkih pokazatelja posmatranih u odnosu na starost, pol i ostale važne determinante zdravlja.

$\mathrm{U}$ ovom radu smo ukratko izneli nekoliko izabranih pristupa kreiranju projekcija koje se koriste za procenu efekata oboljenja KOVID-19 na globalnom i lokalnom nivou (npr. mortalitet u Srbiji).

\section{PROCENA EFEKATA OBOLJENJA KOVID-19 NA GLOBALNOM I LOKALNOM NIVOU}

Nekoliko modela je procenjivalo efekte oboljenja KOVID-19 na globalnom i lokalnom nivou što je dovelo do važnih preporuka od strane raznih zainteresovanih strana. Fridman i saradnici su primetili da na širenje virusa, osim osobina samog virusa i karakteristika oblasti u kojoj se on širi, značajno utiču mere za smanjenje širenja oboljenja, koje je država uvela, kao i koliko se ljudi pridržavaju tih mera. Institut za zdravstvenu metriku i

\section{BACKGROUND}

As the available knowledge grew on the novel coronavirus being the cause of mild, but also severe infections with the possible presence of asymptomatic carriers in the general population, so did the necessity for urgent action in order to prevent suffering, disabilities and economic loss [1-5]. Possible benefits of the implemented mitigation measures for the COVID-19 pandemic are assessed not only by their effects on the course of the pandemic, but also by estimating their direct and indirect economic and social repercussions $[6,7]$.

The progression of the COVID-19 pandemic has challenged many professional planners to try to model the current and future transmission of the novel virus - SARS-CoV-2, in order to achieve a better understanding of its effects in different settings. Epidemiological, political, regulatory, and socio-behavioral changes, as well as increasing knowledge and data, have been used to create different assumptions and flexible estimates of different population exposures to the virus, treatment rates, and outcomes. Projection approaches are constantly evolving using updated data to improve the models $[6,7]$. Mandatory implementation of various public health measures against COVID-19, as well as support and containment measures are decisions made by state officials, primarily imposed in order to protect people's health and lives $[8,9]$. For instance, regulations regarding social distancing and the use of protective face masks were made based on the transmission mode of the virus variant, mobility and population density, as well as the overall public response to the pandemic. Rapid accumulation of data has been used for evaluation and monitoring of various epidemiological and clinical indicators, disaggregated by age, sex and other important determinants of health.

In this article we briefly summarize several selected projection approaches used for the estimation of COVID-19 effects globally and locally (e.g., mortality in Serbia).

\section{ASSESSMENT OF THE COVID-19 GLOBAL AND LOCAL EFFECTS}

Several models have estimated the COVID-19 effects, both globally and locally, leading to important recommendations from various stakeholders. Friedman et al. have noted that, aside from the attributes of the virus itself and characteristics of the location where it is being spread, the trajectory of the COVID-19 epidemic is notably influenced by the state-imposed mitigation measures and our individual compliance to those measures. The Institute for Health Metrics and Evaluation (IHME) has provided multi-level (global, 
evaluaciju (IZME) (engl. The Institute for Health Metrics and Evaluation - IHME) je dao podatke o smrtnosti većoj od očekivane koja se pripisuje oboljenju KOVID-19, za više nivoa (globalni, regionalni, nacionalni i subnacionalni). Ovaj mortalitet se objašnjava kao razlika između broja prijavljenih smrtnih slučajeva, ili stope smrtnosti, i očekivanih stopa smrtnosti/broja smrtnih slučajeva, pružajući na taj način uvid u veliko opterećenje koje KOVID-19 oboljenje donosi svim zemljama. Pošto se zna da broj potvrđenih smrtnih slučajeva od oboljenja KOVID-19 direktno zavisi od sposobnosti neke države da testira stanovništvo tokom nekog vremena, moguće je da se taj broj potceni. Na primer, ovo se dešava kada se radi o pacijentima koji se nalaze u ustanovama za dugoročnu negu. IZME izračunava proporciju smrtnosti koja je iznad očekivane, a koja je rezultat broja smrti iznad očekivanog zbog oboljenja KOVID-19, uzimajući u obzir i ostale uzročnike koji dovode do smrtnosti iznad očekivane, a koji još nisu verifikovani (npr. zakasnelo zdravstveno zbrinjavanje zbog pandemije, porast broja mentalnih poremećaja, zloupotrebe alkohola i opijata, smanjenje broja smrtnih slučajeva izazvanih povredama, ostalim virusima, i kardiovaskularnim i hroničnim respiratornim oboljenjima). U njihovim modelima, povećana smrtnost od oboljenja KOVID-19 je logit funkcija odnosa stope infekcije i detekcije i specifičnosti konteksta. Odnos povećanog broja smrti od KOVID-19 oboljenja i broja prijavljenih smrti od KOVID-19 oboljenja do maja 2021. varira od veoma visokog nivoa u mnogim zemljama istočne Evrope i centralne Azije, do odnosa od malog značaja, u nekoliko bogatih zemalja. Globalno posmatrano, kumulativna stopa povećanog broja smrti od KOVID-19 oboljenja je 91,7 na 100.000 . Prvih pet zemalja sa najvišim procenjenim stopama smrtnosti na 100.000 stanovnika od KOVID-19 oboljenja kao i sa većim stopama smrtnosti od očekivanih od KOVID-19 oboljenja u periodu od marta 2020 do maja 2021, su Azerbejdžan (672,7 odnosno 46,4), Bosna i Hercegovina (601,1 odnosno 268,3 ), Bugarska (559,9 odnosno 245,5), Albanija (528,9 odnosno 88,5) i Meksiko (497,8 odnosno 175,6) [10]. Ove procene će biti revidirane da bi se u obzir uzele nove informacije, posebno drugi činioci koji doprinose opterećenosti društva zbog oboljenja KOVID-19.

Trista osamdeset i šest modela je pokazalo dobru uspešnost u pružanju globalnih predikcija vremena maksimalnog dnevnog mortaliteta izazvanog oboljenjem KOVID-19 [6]. Ovi scenariji predviđanja mortaliteta koriste različite pretpostavke povezane sa sezonama i uključuju različite etape epidemije u nekoj državi (neke države imaju stabilnu konstantnu dinamiku prenošenja zaraze, a neke druge potpuno različite puteve širenja epidemije), kompleksne modele ponašanja regional, national and subnational) estimations of excess mortality due to COVID-19 [10]. Excess mortality is explained as the difference between the number of reported deaths or the mortality rates and the expected mortality numbers/rates, thus providing insight into the COVID-19 burden, in all countries. Knowing that confirmed COVID-19 deaths depend directly on the country's capacity to test over time, it is possible to underestimate this number. For example, this is true for the patients dying in long-term care facilities. IHME estimates the proportion of excess mortality resulting from excess death due to COVID-19, also considering other drivers that affect excess mortality, which have not been verified yet (e.g., delayed health care during the pandemic, increase in mental disorders, alcohol and opiate use, reduction of mortality due to injuries, viruses and cardiovascular and chronic respiratory diseases). In their models, the excess COVID-19 mortality is a logit function of the infection-detection rate and context specifics. Ratios of excess COVID-19 deaths to reported COVID-19 deaths, by May 2021, range from very high levels, in many Eastern European and Central Asian countries, to ratios with low significance in several high-income countries. Globally, the cumulative excess COVID-19 death rate is 91.7 per 100,000 . The top five countries with the highest estimated death rates per 100,000 due to COVID-19, as well as excess COVID-19 death rates in the period from March 2020 to May 2021, are the following: Azerbaijan (672.7 and 46.4, respectively), Bosnia and Herzegovina (601.1 and 268.3, respectively), Bulgaria (559.9 and 245.5, respectively), Albania (528.9 and 88.5, respectively), and Mexico (497.8 and 175.6, respectively) [10]. These estimates will be revised to take into account new information, in particular other COVID-19 burden drivers.

The 386 models have demonstrated good performance in providing global COVID-19 predictions of the time of maximum daily mortality [6]. The forecast-based mortality scenarios use various seasonality assumptions and incorporate different stages of the epidemic per country (some in stabilized ongoing transmission dynamics, others with a completely different epidemic trajectory), complex models of human behavior and government interventions. These model data and codes are publicly available and can be used to compare global, international, and national predictions and assess future performance predictions [11].

A recent evaluation included seven models of the magnitude of COVID-19 mortality. These models were made by IHME [10], DELPHI-MIT [12], Imperial College London [13], Youyang Gu [14], The Los Alamos National Laboratory [15], and the SIKJ-Alpha model from the USC Data Science Lab [16]. Overall, the best-performing 
ljudi i intervencije vlada. Podaci i kodovi iz ovih modela su dostupni javnosti i mogu se koristiti da bi se poredila globalna, međunarodna i nacionalna predviđanja kao i da bi se procenila uspešnost budućih predviđanja [11].

Jedna nedavna procena je obuhvatila sedam modela koji su se bavili veličinom mortaliteta povezanog sa oboljenjem KOVID-19. Ove modele su kreirali: IZME [10], DELPHI-MIT [12], Imperijalni koledž u Londonu (engl. Imperial College London), Jujang Gu [14], Nacionalna laboratorija, Los Alamos (engl. The Los Alamos National Laboratory) [15], i SIKJ-Alpha model iz Naučne laboratorije Univerziteta iz Južne Kalifornije (engl. USC Data Science Lab) [16]. Gledajući sveukupno, najuspešniji model je varirao po regionima, međutim, najveće greške u predviđanju su među zemljama na južnoj hemisferi a za njima su sledile neke zemlje iz severne hemisfere (istočna Evropa, centralna Azija i bogate zemlje). Poređenje vremena kada je dolazilo do vrhunca dnevnog mortaliteta je pokazalo da se u najdužim predviđanjima mogu javljati greške u procenama koje idu od 1,0\% nakon jedne nedelje do 26,9\% nakon 12 nedelja ekstrapolacije.

Još jedan model koji je koristio IZME tim za predviđanja vezana za KOVID-19 oboljenje, je SEIR model koji je utvrdio moguće puteve prenošenja infekcije izazvane SARS-KOV-2 virusom u Sjedinjenim Američkim Državama tokom perioda od šest meseci u odnosu na efekte nefarmaceutskih intervencija [6]. Ovaj SEIR model je koristio podatke o smrtnim ishodima, oporavljenim i inficiranim osobama i osobama koje su izložene i osetljive na KOVID-19 tokom perioda od osam meseci. Ovaj model je prilagodio projekcije za kovarijate kao što su stopa testiranja, mobilnost, sezonske pneumonije, i korišćenje maski, po glavi stanovnika. Za svaku državu u Americi procenjen je značajan broj potencijalnih života koji bi se mogli spasiti na osnovu određenih propisanih mera socijalnog distanciranja. U mnogim državama nošenje zaštitne maske za lice $u$ javnom okruženju moglo bi da bude dovoljno da ublaži najgore efekte ponovne pojave epidemije [6].

\section{KOVID-19 U SRBIJ}

Srpski Zakon o zaštiti stanovništva od zaraznih bolesti prepoznaje Institut za javno zdravlje Srbije "Dr Milan Jovanović Batut" (IJZS) kao centralnu instituciju za zdravstveni nadzor i sakupljanje podataka [17]. Od početka pandemije IJZS izdaje dnevne izveštaje o epidemiološkoj situaciji u zemlji. Ovi izveštaji se distribuiraju putem raznih medijskih kanala a tumače ih zvaničnici Vlade i Ministarstva zdravlja.

Na osnovu podataka o praćenju koje je dao IJZS za period od prvog registrovanog slučaja oboljenja KOVID-19 (6. mart 2020.) do današnjeg dana (29. jul 2021.), kumulativni broj testiranih osoba je bio 4.653.071, dok model varied by region, however, the highest predicting errors were seen among countries in the Southern Hemisphere followed by those in the Northern Hemisphere (Eastern Europe and Central Asia and high-income countries). Comparison of the peak daily mortality timing showed that longer forecasts can yield errors in estimates from $1.0 \%$ at 1 week to $26.9 \%$ at 12 weeks of extrapolation.

Another model used by the IHME COVID-19 forecasting team was the SEIR model, which identified possible routes of the infection caused by the SARS-CoV-2 virus, in the United States, during a six-month period, in relation to the effects of non-pharmaceutical interventions [6]. This SEIR model used a database of deaths, recovered, infected, exposed and susceptible COVID-19 cases, spanning over a period of eight months. The model adjusted the projections for covariates such as test rates, mobility, seasonality of pneumonia, and use of masks per capita. For each state, the significant number of potential lives which could be saved by certain mandates of social distancing has been estimated. In many states, the use of protective face masks in public settings might be sufficient to mitigate the worst effects of the re-emergence of the epidemic [6].

\section{COVID-19 IN SERBIA}

Serbian Law on Protection of the Population Against Communicable Diseases recognizes the Institute of Public Health of Serbia Dr Milan Jovanović Batut (IPHOS) as the central institution for health surveillance and data collection [17]. Since the beginning of the pandemic, IPHOS has been publishing daily reports on the epidemiological situation in the country. The reports are disseminated through various media channels and interpreted by government officials and the Ministry of Health.

Based on the surveillance database of the IPHOS [18], in the period from the first registered case of COVID-19 (March 6, 2020) until the present day (July $29,2021)$, the cumulative number of tested persons is $4,653,071$, while the total number of confirmed cases is 721,267 . In the same period, the greatest number of daily confirmed cases was 7,999, on December 1, 2020, the greatest number of daily confirmed deaths was 69 , on December 4, 2020, and the greatest number of hospitalized COVID-19 patients was 9,728 on December 28, 2020 [18].

Before this article was submitted, the latest data was reported on July 29, 2021, which showed 292 new confirmed cases [18]. Also, clinical manifestations of COVID-19 have been continuously monitored, showing that the greatest number of patients requiring mechanical ventilation was 353, on December 17, 2020, 
je ukupan broj potvrđenih slučajeva bio 721.267. U istom periodu najveći broj potvrđenih slučajeva je bio 7.999, i to 1. decembra 2020., najveći broj potvrđenih smrti u jednom danu je bio 69, 4. decembra 2020., a najveći broj pacijenata hospitalizovanih zbog oboljenja KOVID-19 je bio 9.728, 28. decembra 2020. [18].

Najnoviji podaci koji su izašli pre nego što je ovaj rad predat bili su za 29. jul 2021. prema kojima je bilo 292 nova potvrđena slučaja [18]. Osim toga, stalno se prate kliničke manifestacije oboljenja KOVID-19 i ti podaci pokazuju da je najveći broj pacijenata koji zahtevaju mehaničku ventilaciju bio 353,17 . decembra 2020. dok je nedavno, 29. jula 2021., 13 osoba zahtevalo mehaničku ventilaciju i nije bilo ni jedne potvrđene smrti od oboljenja KOVID-19 [18] . Kumulativni broj potvrđenih smrti zbog oboljenja KOVID-19 je 7.110 prema podacima IJZS-u, ali ovaj broj ne uključuje nepotvrđene slučajeve. Ova pandemija je uticala i na obrasce mortaliteta u Srbiji. Republički zavod za statistiku Srbije (RZS) je 26. jula 2021. izdao zvanični izveštaj o živim novorođenim bebama i o smrtnim ishodima za period januar jun 2021. [19]. Prema njihovim podacima, broj smrtnih ishoda je u ovom periodu bio 65.817, što predstavlja povećanje od $14.248(+27,8 \%)$ u poređenju sa 2020. godinom [20]. Kao što je već rečeno, ovaj porast u broju prijavljenih smrti, u poređenju sa brojevima očekivanog mortaliteta, može se jednostavno nazvati povećani mortalitet odnosno mortalitet veći od očekivanog.

Ako posmatramo mortalitet veći od očekivanog u periodu januar - jun 2021. u četiri glavne geografske regije u Srbiji, vidimo da je na vrhu zapadna Srbija sa povećanjem od 30,5\%, sledi region Beograda $(+28,6 \%)$, Vojvodina $(+24,9 \%)$ pa istočna i južna Srbija $(+23,7 \%)$ [19].

Međutim, važno je još jednom naglasiti da mortalitet veći od očekivanog nije jednostavno jednak kumulativnom broju smrti koje su povezane sa oboljenjem KOVID-19. Da bi se procenio kumulativni broj smrti od KOVID-19 oboljenja mnogi faktori koji utiču na dinamiku mortaliteta većeg od očekivanog moraju se uzeti u obzir. Neki od ovih faktora smanjuju očekivani mortalitet zbog smanjene mobilnosti i socijalnog distanciranja. Na primer, do smanjenja mortaliteta dolazi zbog smanjenja broja povreda ili redukovane transmisije drugih virusa. Sa druge strane, mortalitet veći od očekivanog može se povećati zbog većeg broja mentalnih poremećaja ili neadekvatnog lečenja hroničnih nezaraznih bolesti [10] . Do ovog momenta, prema podacima iz RZS-a, decembar 2020. je bio mesec sa najvećim mortalitetom u odnosu na očekivani tokom epidemije u Srbiji. Ako pogledamo preliminarne podatke iz službenog statističkog izveštaja za decembar 2020. videćemo da je registrovani broj smrti bio 17.321 u poređenju sa 8.803 u decembru 2019., što je porast while recently (on July 29,2021$) 13$ people required mechanical ventilation, and there were zero confirmed COVID-19 deaths [18]. The cumulative number of confirmed COVID-19 deaths is 7,110, according to IPHOS, but this number does not include unconfirmed cases. The pandemic has affected the mortality patterns in Serbia. On July 26, 2021, the Statistical Office of the Republic of Serbia (SORS) issued an official release on live births and deaths in the period of January to June 2021 [19]. According to their data, the number of deaths in this period amounted to 65,817 , which represents an increase of $14,248(+27.8 \%)$ as compared to 2020 [20]. As stated earlier, this increase in the reported number of deaths, as compared to the expected mortality numbers, can simply be called excess mortality.

If we observe the excess mortality in the period from January to June 2021, in the four main geographical regions of Serbia, West Serbia leads with an increase of $30.5 \%$, followed by the Region of Belgrade $(+28.6 \%)$, Vojvodina $(+24.9 \%)$ and East and South Serbia $(+23,7 \%)$ [19].

However, it is important to emphasize, once again, that excess mortality is not simply equal to the cumulative number of COVID-19 related deaths. To estimate the cumulative number of COVID-19 deaths, many factors, which influence the dynamics of excess mortality during the pandemic, have to be taken into consideration. Some of these factors decrease the expected mortality, due to the reduction in mobility and social distancing. For example, there is a reduction in mortality due to a decrease in injuries or reduced transmission of other viruses. On the other hand, excess mortality can increase due to an increase in mental health disorders or inadequate management of chronic non-communicable diseases [10]. Up to this point, December 2020 was the month with the highest excess mortality during the epidemic in Serbia, according to the Statistical Office. If we look at the preliminary data from the official statistical report for December 2020, the registered number of deaths was 17,321 , as compared to 8,803 in December 2019, which is an increase of 8,518 (+96.8\%) [20]. It is important to note that the SORS calculates excess mortality by comparing the number of deaths between two consecutive years. Limitations to this approach are evident in case of phenomena which have a long-term demographic impact. In that sense, when evaluating short- and long-term impacts of an epidemic, different statistical approaches should be used to avoid under- or overestimating its effects.

Finally, if we calculate the cumulative excess mortality due to the epidemic in Serbia, according to the official data, that number amounts to 14,628 in 2020 (from March to December) and 14,248, thus far in 
od 8.518 (+96,8\%) [20]. Važno je da se istakne da RZS obračunava mortalitet veći od očekivanog poredeći brojeve smrti iz dve uzastopne godine. Ograničenja ovakvog pristupa su očigledna kada se radi o pojavama koje imaju dugoročni uticaj na demografiju. $U$ tom smislu, kada se porede kratkoročni i dugoročni uticaji neke epidemije, potrebno je koristiti različite statističke pristupe kako bi se izbegla nedovoljna ili prekomerna procena efekata te epidemije.

Na kraju, ako računamo kumulativni mortalitet veći od očekivanog zbog epidemije u Srbiji, prema zvaničnim podacima, taj broj iznosi 14.628 u 2020. (od marta do decembra) i 14.248 do sada u 2021. (od januara do juna) što ukupno čini $28.876[19,20]$. Do ovog momenta, Ministarstvo zdravlja Srbije izdalo je samo jednu zvaničnu reviziju brojeva o mortalitetu od KOVID-19 oboljenja (30. juna 2021.) potvrdivši 10.356 smrti od KOVID-19 oboljenja.

\section{PUT KOJIM TREBA IĆI U BUDUĆNOSTI}

Do sada je stotine modela za predviđanje objavljeno i/ili izneto $u$ javnost i često nije odmah jasno koji modeli su najuspešniji ili najbolje odgovaraju za predviđanje datog aspekta pandemije. Postojeći modeli za predviđanje koji se odnose na KOVID-19 oboljenje se znatno razlikuju po metodologiji, pretpostavkama, opsegu predviđanja i procenjenim vrednostima, čak i kod kratkoročnih procena za isto mesto. Zbog toga je važno da se naglasi da se najveća korist od kreiranja modela ogleda u njegovom uticaju na društvo. Najbolje je da donosioci odluka zasnivaju svoja delovanja na primenjenim modelima i na taj način, potencijalno, utiču na hiljade života, pa je zbog toga neophodno da se ti modeli prvo procene korišćenjem specijalnih statističkih metoda. Samo verifikovani modeli, oni za koje je dokazano da su validni i kredibilni, pružaju pravi uvid u razne efekte pandemije.

U ovom kontekstu, korisni uvidi koji se dobijaju zavaljujući modelovanju, treba da prate i kohortne studije koje govore o tome koliko godina života ljudi je sačuvano za vreme KOVID-19 pandemije kroz kombinaciju efekata mera za očuvanje zdravlja ljudi i efikasnosti vakcina. Veliki intervali neizvesnosti koji prate procene za dužu ekstrapolaciju u vezi sa mortalitetom povezanim sa KOVID-19 oboljenjem i njihovi pikovi sugerišu da se usvoji takav strateški pristup zdravstvenim sistemima po kome bi se odluke donosile na osnovu stalnog priliva informacija, verifikacije i ažuriranja modela.

Kreiranje modela za globalne i lokalne efekte oboljenja KOVID-19 je od ogromnog značaja jer se javne zdravstvene službe moraju pripremiti za potencijalno hitne potrebe za novim radnicima, zalihama i kapacitetima. Na primer, bolnice moraju doneti strateške odluke koje se tiču dugoročnog planiranja resursa kao što
2021 (from January to June) making a grand total of $28,876[19,20]$. Up to this moment, the Serbian Ministry of Health has issued just one official revision of the COVID-19 mortality numbers, June 30,2021 , confirming 10,356 COVID-19 related deaths.

\section{THE WAY FORWARD}

Hundreds of forecasting models have been published and/or publicly released, and it is often not immediately clear which models have had the best performance or are most appropriate for predicting a given aspect of the pandemic. Existing COVID-19 prediction models differ significantly in methodology, assumptions, prediction range, and estimated values, even in shortterm estimates for the same site. Therefore, it is important to emphasize that the greatest benefit of modeling is the social impact it generates. Ideally, decision makers will base their actions on the applied models, therefore potentially affecting thousands of lives, so the models must first be assessed with special statistical tools. Only verified models, those proven to be valid and credible, provide real insight into the various effects of the pandemic [21].

In this context, useful modeling insights should be accompanied by cohort studies reporting years of lives saved through the combined effects of public health measures and vaccine effectiveness, during the COVID-19 pandemic. Wide uncertainty intervals that accompany assessments made for longer extrapolation of COVID-19 related mortality and their peaks suggest the adoption of a health systems strategic approach for decision-making based on continuous information, verification and updates of the models.

Modeling the COVID-19 global and local effects is of immense public value, as public health facilities must prepare for potential urgent needs for workers, supplies and capacities. For instance, hospitals need to make strategic decisions regarding long ranging resources such as health workers, beds, intensive care beds and ventilators [6]. Similarly, the effects of COVID-19 on the economy and education sector need to be predicted [22], in order to reduce consequent unemployment and poverty [23].

\section{CONCLUSION}

Given the complexity of predicting human behavior and political decisions, the abovementioned modelling efforts are providing consistent direction of projections trajectories. Due to wide uncertainty intervals, joint action of various stakeholders is required for continuous improvement of the models' power and credibility. 
su zdravstveni radnici, broj kreveta, broj kreveta u intenzivnoj nezi i broj mehaničkih respiratora [6]. Na isti način se moraju predvideti i efekti koje KOVID-19 ima na ekonomiju i sektor obrazovanja [22], kako bi se smanjili nezaposlenost i siromaštvo koji mogu uslediti [23].

\section{ZAKLJUČAK}

S obzirom na složenost predviđanja ponašanja ljudi i donošenja političkih odluka, gorenavedeni napori za stvaranje modela pružaju dosledan pravac za buduće projekcije. Zbog velikih intervala neizvesnosti neophodno je udruženo delovanje raznih zainteresovanih strana za stalno unapređivanje mogućnosti i kredibiliteta modela.

\section{SKRAĆENICE}

KOVID-19 - bolest izazvana koronavirusom 2019

GODB - globalno opterećenje društva bolešču (engl. GBD - Global Burden of Disease)

IZME - Institut za zdravstvenu metriku i evaluaciju (engl. IHME - Institute for Health Metrics and Evaluation)

IJZS - Intitut za javno zdravlje Srbije

MIT - Institut za tehnologiju iz Masačusetsa (engl. MIT - Massachusetts Institute of Technology)

SARS-KoV-2 - tip 2 koronavirusa - izazivač teškog akutnog respiratornog sindroma (engl. SARS-CoV-2 - Severe Acute Respiratory Syndrome Coronavirus 2)

RZS - Republički zavod za statistiku Srbije

USC - Univerzitet iz San Franciska (engl. USC - University of San Francisco)

\section{Izjave zahvalnosti}

Autori su članovi GODB mreže saradnika Instituta za zdravstvenu metriku i evaluaciju (IZME), Univerziteta u Sijetlu u državi Vašingtoton, SAD. Ovu publikaciju je podržao COST Action CA18218 (Evropska mreža za opterećenost društva bolešću); https://www.burdeneu.net/ koju je podržao COST (Evropska kooperacija u nauci i tehnologiji; https://www.burden-eu.net).

Sukob interesa: Nije prijavljen.

\section{LITERATURA / REFERENCES}

1. Davies NG, Klepac P, Liu Y, Prem K, Jit M, Eggo RM. Age-dependent effects in the transmission and control of Covid-19 epidemics. Nature Medicine. 2020;26:1205-11. doi:10.1038/s41591-020-0962-9.

2. Gémes K, Talbäck M, Modig K, Ahlbom A, Berglund A, Feychting M, et al. Burden and prevalence of prognostic factors for Severe COVID-19 in Sweden. European Journal of Epidemiology. 2020;35:401-9. doi:10.1007/s10654-020-00646-z.

3. Gostin L0. The Coronavirus Pandemic 1 Year On-What Went Wrong? JAMA. 2021;325:1132. doi:10.1001/jama.2021.3207.

4. Krouse HJ. COVID-19 and the Widening Gap in HEALTH Inequity. Otolaryngology-Head and Neck Surgery. 2020;163:65-6. doi:10.1177/0194599820926463.

\section{ABBREVIATIONS AND ACRONYMS}

COVID-19 - coronavirus disease of 2019

GBD - Global Burden of Disease

IHME - Institute for Health Metrics and Evaluation

IPHOS - Institute of Public Health of Serbia

MIT - Massachusetts Institute of Technology

SARS-CoV-2 - Severe Acute Respiratory Syndrome Coronavirus 2

SORS - Statistical Office of the Republic of Serbia

USC - University of San Francisco

\section{Acknowledgements}

The authors are members of the GBD Network of Collaborators of the Institute for Health Metrics and Evaluation (IHME), University of Washington, Seattle, USA. This publication is supported by COST Action CA 18218 (European Network for Disease Burden); https://www. burden-eu.net/ supported by COST (European Cooperation in Science and Technology; https://www.burden-eu.net).

Conflict of interest: None declared.

5. Wyper GM, Assunção R, Cuschieri S, Devleesschauwer B, Fletcher E, Haagsma JA, et al. Population vulnerability to COVID-19 in Europe: A burden of disease analysis. Archives of Public Health. 2020;78. doi:10.1186/s13690-02000433-y.

6. Friedman J, Liu P, Troeger CE, Carter A, Reiner RC, Barber RM, et al. Predictive performance of international COVID-19 mortality forecasting models. Nature Communications. 2021;12. doi:10.1038/s41467-021-22457-w.

7. Reiner RC, Barber RM, Collins JK, Zheng P, Adolph C, Albright J, et al. Modeling COVID-19 scenarios for the United States. Nature Medicine. 2020;27:94-105. doi:10.1038/s41591-020-1132-9. 
8. Kandel N, Chungong S, Omaar A, Xing J. Health security capacities in the context of Covid-19 outbreak: An analysis of international health Regulations annual report data from 182 countries. The Lancet. 2020;395:1047-53. doi:10.1016/s0140-6736(20)30553-5.

9. Neogi SB, Preetha GS. Assessing health systems' responsiveness in tackling COVID-19 pandemic. Indian Journal of Public Health. 2020;64:211. doi:10.4103/ijph.ijph_471_20.

10. Estimation of excess mortality due to COVID-19 [Internet]. Institute for Health Metrics and Evaluation. [Internet]. Available on: http://www.healthdata.org/node/8660 [Accessed on 27 July 2021].

11. Global COVID-19 Forecast Comparison [Internet]. GitHub. 2021. Available on: https://github.com/pyliu47/covidcompare [Accessed on 27 July 2021].

12. Li ML, Bouardi HT, Lami OS, Trikalinos TA, Trichakis NK, Bertsimas D. Forecasting covid-19 and analyzing the effect of government interventions. 2020. do i: $10.1101 / 2020.06 .23 .20138693$.

13. Forecasting the Healthcare Burden of COVID-19 in LMICs [Internet]. Imperial College London., \& MRC Centre for Global Infectious Disease Analysis. 2020. Available on: https://mrc-ide.github.io/global-Imic-reports/ [Accessed on 27 July 2021].

14. COVID-19 projections using machine learning [Internet]. Gu, Y. 2020. Available on: https://covid19-projections.com/ [Accessed on 27 July 2021].

15. COVID-19 Confirmed and Forecasted Case Data [Internet]. Los Alamos national Laboratory COVID-19 Team. Available on: https://covid-19.bsvgateway. org/ [Accessed on 27 July 2021].

16. Fast and Accurate Forecasting of COVID-19 Deaths [Internet]. Srivastava, A., Xu, T. 2020. Available on: http://arxiv.org/abs/2007.05180 [Accessed on 27 July 2021].
17. COVID-19 National Info page [Internet]. Ministry of Health, Republic of Serbia. 2020. Available on: https://covid19.data.gov.rs [Accessed on 27 July 2021].

18. COVID-19 Statistics in Serbia [Internet]. Ministry of Health, Republic of Serbia. 2020. Available on: https://covid19.rs/homepage-english [Accessed on 27 July 2021].

19. Statistical release Number 203 - Year LXXI, 26 July 2021 live births and deaths, January-June 2021. SORS - Statistical Office of Serbia. 2021. Available on: https://publikacije.stat.gov.rs/G2021/PdfE/G20211203.pdf [Accessed on 27 July 2021].

20. Statistical release Number 017 - Year LXXI, 25 January 2021 live births and deaths, January-December 2020. SORS - Statistical Office of Serbia. 2021. Available on: https://publikacije.stat.gov.rs/G2021/PdfE/G20211017.pdf [Accessed on 27 July 2021].

21. Tashman LJ. Out-of-sample tests of forecasting accuracy: An analysis and review. International Journal of Forecasting 2000;16:437-50. doi:10.1016/ s0169-2070(00)00065-0.

22. Viner RM, Russell SJ, Croker H, Packer J, Ward J, Stansfield C, et al. School closure and management practices during coronavirus outbreaks including covid-19: a rapid systematic review. The Lancet Child \& Adolescent Health 2020;4:397-404. doi:10.1016/s2352-4642(20)30095-x.

23. Atkeson, A. What Will Be the Economic Impact of Covid-19 in the Us? Rough Estimates of Disease Scenarios. 2020. U: Nber Working Paper Series (NBER Working Papers, Issue 26867). National Bureau of Economic Research, Inc. 